\title{
The Auricular VX2 Carcinoma Is a Suitable Animal Model for Identifying Biomarkers for HNSCC Therapy Response
}

\author{
MICHAEL BETTE ${ }^{1}$, ANNETTE NOWAK-ROSSMANN ${ }^{1,2}$ and ROBERT MANDIC ${ }^{2}$ \\ ${ }^{I}$ Department of Molecular Neuroscience, Institute of Anatomy and Cell Biology, \\ Philipps University Marburg, Marburg, Germany; \\ ${ }^{2}$ Department of Otorhinolaryngology, Head and Neck Surgery, \\ University Hospital Giessen and Marburg, Campus Marburg, Marburg, Germany
}

\begin{abstract}
Background/Aim: The rabbit auricular VX2 carcinoma is an established animal model for human head and neck squamous cell carcinoma (HNSCC). Previously, we observed that intraperitoneal oxidative $\left(\mathrm{O}_{3} / \mathrm{O}_{2}\right)$ stress induced tumor remission. Our aim was to evaluate candidate genes associated with tumor regression. Materials and Methods: For identification of tumor remission-related genes, microarray analysis was performed with subsequent validation by polymerase chain reaction (PCR), in situ hybridization, immunohistochemistry and western blot analysis. Results: Microarray analysis indicated a prominent reduction of epidermal growth factor receptor (Egfr, Erbbl) expression levels in regressing tumors. Quantitative PCR confirmed a significant $(p<0.005)$ down-regulation of Erbb13 mRNA in regressing VX2 tumors. Histological localization of Erbb1-3 mRNA transcript and protein indicated reduced Erbb gene expression occurring at the level of individual $V X 2$ tumor cells rather than solely being an effect of tumor shrinkage. This study highlights changes in the Erbb gene signature of regressing VX2 carcinomas as a predictor for therapy response. The VX2 carcinoma animal model, therefore, appears suitable for the identification and evaluation of new diagnostic, prognostic and therapeutic biomarkers prior to their application in patients with HNSCC.
\end{abstract}

The epidermal growth factor receptor (EGFR) family comprises four distinct receptor tyrosine kinases (RTKs): EGFR (also known as ERBB1/HER1), ERBB2 (HER2, neu),

Correspondence to: Michael Bette, Ph.D., Institute of Anatomy and Cell Biology, Philipps-University Marburg, Robert-Koch-Street 8, 35037 Marburg, Germany. Tel: +49 64212866780, Fax: +49 64212868965, e-mail: bette@staff.uni-marburg.de

Key Words: EGFR, ErbB, HNSCC, ozone, therapy.
ERBB3 (HER3) and ERBB4 (HER4). ERBB receptors trigger intracellular signals promoting cellular differentiation, proliferation, survival and migration thereby being critical in embryonic development, tissue repair and renewal, as well as in cancer biology. Since first reports demonstrated EGFR to be related to the transforming protein encoded by the v-erb-B oncogene of avian erythroblastosis virus (1), the role of ERBB receptors in cancer development has been studied intensely (2). In fact, aberrant ERBB activity has been described in a variety of human epithelial cancer types $(2,3)$ including head and neck squamous cell carcinomas (HNSCC) (4), which are the most frequent malignancies of the upper aerodigestive tract. Overexpression of EGFR has been verified in up to $90 \%$ of all $\operatorname{HNSCC}(5,6)$ and numerous studies have demonstrated that EGFR can be used as a prognostic factor to predict tumor growth, therapy sensitivity and risk of recurrences (7-9). Overexpression of other ERBB family members, such as ERBB2 and ERBB3 have been described in ovarian and breast cancer as well as HNSCC (10-13).

In order to identify candidate genes and unravel molecular and cellular changes present in regressing VX2 tumors, we experimentally deployed the auricular VX2 carcinoma animal model of the New Zealand White (NZW) rabbit. This animal model exhibits analogous growth features to those observed in HNSCCs $(14,15)$. Similar to human papillomavirus-related HNSCCs, the VX2 carcinoma is also associated with a papillomavirus, the so-called Shope cottontail rabbit papillomavirus $(16,17)$. In the VX2 model, a squamous cell tumor develops after implantation of VX2 tumor cell suspension into the subcutis of the rabbit auricle, which later tends to metastasize regionally to cervical lymph nodes, as well as distantly to organs such as the lung. This pattern of metastatic spread of the VX2 tumor strongly resembles the biological behavior of human HNSCC and is one main reason why the VX2 tumor has become a valuable tool in head and neck cancer research. 
Previously, we reported that a strong oxidative stress applied intraperitoneally $\left(\mathrm{O}_{3} / \mathrm{O}_{2}\right.$-pneumoperitoneum, $\mathrm{O}_{3} / \mathrm{O}_{2^{-}}$ $\mathrm{PP})$ to $\mathrm{VX} 2$ carcinoma-bearing rabbits resulted in remission of the tumor and prevention of associated metastasis in a significant number of animals (18). The exact underlying mechanisms of this therapeutic approach are still unknown, but given that NZW rabbits are equipped with an intact immune system, the body's own immune system is most likely involved since reimplantation of the VX2 tumor in cured rabbits was only possible after immune suppression with dexamethasone and cyclosporine A (19). The role of the immune system was further supported by the observation that adoptive transfer of leukocytes from rabbits with regressive VX2 carcinomas into those with progressive tumor led to tumor remission in the recipient animals (16).

The aim of the study was therefore to evaluate in more detail the expression level of EGFR and other members of the ERBB family of RTKs in progressive and regressive VX2 tumors.

\section{Materials and Methods}

Animals. Animal experiments were approved by the regional board in Giessen, Germany [V54-19c20-15(1) MR20/26 Nr.A22/2008 and V54-19c20-15(1) MR20/26 Nr.34/2011] according to the German Animal Protection Law. Overall 28 adult Iffa Credo NZW rabbits (Charles River, Wiga, Germany) with a body weight (BW) range of 2.0 to $3.0 \mathrm{~kg}$ were used; four animals served as donors of the VX2 cell suspension used for the induction of auricular tumors. Rabbits were kept in individual steel cages under standardized air conditioning $\left(20-22^{\circ} \mathrm{C}, 50-60 \%\right.$ humidity) under a $12 \mathrm{~h}$ artificial day/night rhythm with access to food and water ad libitum. Animals were acclimatized for at least 7 days in the hutch prior to starting the experiment. For surgical ablation of the auricular tumor, animals were sedated by Robinul ${ }^{\circledR}(0.1 \mathrm{ml} / \mathrm{kg} \mathrm{BW}$; Riemser Arzneimittel AG, Greifswald, Germany) subcutaneously (s.c.) and anesthetized by a mixture of Rompun ${ }^{\circledR}(5 \mathrm{mg} / \mathrm{kg}$ BW; Bayer Vital $\mathrm{GmbH}$, Leverkusen, Germany)/Ketavet ${ }^{\circledR}(70 \mathrm{mg} / \mathrm{kg} \mathrm{BW}$; Pharmacia GmbH, Berlin, Germany) intramuscularly. Analgesic treatment s.c. with Temgesic ${ }^{\circledR}$ (Essex Pharma GmbH, Munich, Germany) was started $2 \mathrm{~h}$ before surgical intervention and maintained for at least 2 days and dependent on wound-healing progression. Signs of distress, pain or cachexia, defined as weight loss above $20 \%$, were criteria for euthanasia.

Experimental design. Auricular VX2 tumors were implanted into the left ear of $24 \mathrm{NZW}$ rabbits by s.c. injection of $5 \times 10^{7}$ tumor cells derived from a donor rabbit as described elsewhere (19). Tumor volume was measured daily with a digital caliper and growth was allowed to continue until the solid auricular tumor had reached a volume of $>2,500 \mathrm{~mm}^{3}$. At this stage, the animals were alternately assigned to one of two experimental groups: i) animals that received intraperitoneal oxidative stress $\left(\mathrm{O}_{3} / \mathrm{O}_{2}-\mathrm{PP}\right)$; or ii) sham-treated animals that received anesthesia and a puncture into the peritoneum but without gas insufflation.

The $\mathrm{O}_{3} / \mathrm{O}_{2}$-PP therapy consisted of daily intraperitoneal insufflation of a medical $\mathrm{O}_{3} / \mathrm{O}_{2}$ gas mixture (Medozon ${ }^{\mathrm{IP}}$; Herrmann
Apparatebau GmbH, Kleinwallstadt, Germany) under anesthesia (70 $\mathrm{mg} / \mathrm{kg}$ ketamine $/ 20 \mathrm{mg} / \mathrm{kg}$ xylazine) over a period of 5 consecutive days. The $\mathrm{O}_{3} / \mathrm{O}_{2}$ gas mixture was applied in a standardized volume of $80 \mathrm{ml} / \mathrm{kg} \mathrm{BW}$ containing $50 \mu \mathrm{g} \mathrm{O}_{3}$ per $\mathrm{ml}$ gas mixture corresponding to $2.5 \% \mathrm{O}_{3}$ and $97.5 \%$ medical $\mathrm{O}_{2}$. For a detailed description see Schulz et al. (19).

Tumor size was documented daily with a digital caliper and tumor development was classified as progressive when the tumor volume reached more than $6,000 \mathrm{~mm}^{3}$, or designated as in remission when the volume dropped below $50 \%$ of its maximal value. These volumes were based on previous personal observations that once a tumor decreased or increased to one of these levels it either totally disappeared or progressively grew leading to the animal's death within 2 months due to massive tumor bleeding or abundant lung metastases. Once an auricular VX2 tumor reached these criteria it was surgically removed as described earlier (18) and tissue samples were stored in RNAlater (Sigma-Aldrich, Darmstadt, Germany) to be used in downstream applications such as quantitative reverse transcription (qRT) - PCR and microarray analysis. In addition, tissues were cryoprotected in Tissue-Tek ${ }^{\circledR}$ O.C.T. Compound (Sakura Finetek, Torrance, CA, USA) for in situ hybridization (ISH) analysis, or fixed in $4 \%$ formaldehyde solution (i.e. formalin) to be used in formalin-fixed paraffin-embedded (FFPE) immunohistochemistry.

Microarray analysis. Total mRNA was isolated from two progressive and two regressive auricular VX2 tumors using RNeasy Mini kit (Qiagen, Hilden, Germany) according to the manufacturer's protocol. RNA was validated with the Experion ${ }^{\mathrm{TM}}$ Automated Electrophoresis System (BioRad Laboratories Inc., Dreieich, Germany) and subsequently deployed for microarray analysis (one slide, four microarrays/slide; Format: $4 \times 44 \mathrm{~K}$, product \#: G2519F, Design ID: 020908; Agilent Technologies, Santa Clara, CA, USA). This microarray represents 42,034 gene fragments that are based on gene information obtained from the RefSeq (Release 29, May 2008), Unigene (Build 11, Mar 2008) and Ensembl (Release 49, Feb 2006) databases. Microarray analysis, as well as pre-evaluation of the raw gene-expression data, were carried out at the EMBL GeneCore Facility (European Molecular Biology Laboratory, Heidelberg, Germany).

Quantification of Erbb and mitogen-activated protein kinase kinase 1 (Mapk2k1) mRNA in VX2 tumor tissues. All tumor tissues were homogenized with Precellys ${ }^{\circledR}$ Homogenizer (Peqlab Biotechnologie $\mathrm{GmbH}$, Erlangen, Germany). Total RNA was isolated using RNeasy Mini kit (Qiagen) according to the manufacturer's protocol and single-strand cDNA was synthesized from $0.5 \mu \mathrm{g}$ total RNA using $\mathrm{RT}^{2}$ first strand kit (Qiagen). For Erbb and Mapk2k1 mRNA quantification by qRT-PCR, Power SybrGreen PCR Master Mix (Applied Biosystems, Darmstadt, Germany) was used in combination with the respective primer pairs (Invitrogen, Darmstadt, Germany) as listed in Table I. PCR was performed with 1 cycle at $95^{\circ} \mathrm{C}$ for $10 \mathrm{~min}, 40$ cycles at $95^{\circ} \mathrm{C}$ for $15 \mathrm{~s}$ and $60^{\circ} \mathrm{C}$ for $15 \mathrm{~s}$ ) afterwards followed by a dissociation curve with $95^{\circ} \mathrm{C}$ for $15 \mathrm{~s}$, increasing temperature from 60 to $90^{\circ} \mathrm{C}$ and afterwards 1 cycle at $95^{\circ} \mathrm{C}$ for $10 \mathrm{~min}$. Rabbit Erbb mRNA was normalized to the respective amount of rabbit glyceraldehyde 3-phosphate dehydrogenase (Gapdh; NM_001082253.1) mRNA in each sample. Samples were run in triplicate. The cycle threshold $\left(\mathrm{C}_{t}\right)$ cut-off value for all measurements was 35 . For relative quantification, an efficiency of $100 \%$ was assumed for all primer pairs. For absolute 
Table I. Summary of oligonucleotide primer pairs used in this study.

\begin{tabular}{|c|c|c|c|c|}
\hline Application & Primer pair & Direction & Sequence $5^{\prime}-3^{\prime}$ & Length of amplicon (bp) \\
\hline \multirow[t]{2}{*}{ qPCR } & Gapdh & Forward & GG CAG GGA TGA TGT TCT GGG & 193 \\
\hline & & Reverse & GAT TGT CAG CAA CGC ATC CT & \\
\hline \multirow[t]{2}{*}{ qPCR } & Egfr & Forward & AGA TGG CGT CCG CAA GT & 102 \\
\hline & & Reverse & GTG GCA TTT ATG GAC AAC G & \\
\hline \multirow[t]{2}{*}{ qPCR } & Erbb2 & Forward & GAC CAC CTG TCC CTA CAA CTA CCT & 124 \\
\hline & & Reverse & GGG CTT GCT GCA TTT CTC A & \\
\hline \multirow[t]{2}{*}{ qPCR } & Erbb3 & Forward & TTT CCA ACC TCA CGA CCA T & 128 \\
\hline & & Reverse & GAT ACG CCC AGC ACT AAT CT & \\
\hline \multirow[t]{2}{*}{ qPCR } & Erbb4 & Forward & CAA TGC GAA GTA CAC CTA T & 180 \\
\hline & & Reverse & GTG CCA ATA CCA TCA CAA G & \\
\hline \multirow[t]{2}{*}{ ISH } & Egfr & Forward & CGG AGC CAA CAA GAC CGG GC & 988 \\
\hline & & Reverse & TTG GAG GGA GCG CAG TCC C & \\
\hline \multirow[t]{2}{*}{ ISH } & Erbb2 & Forward & ACA ACC AGC TGG CCC TCA CG & 974 \\
\hline & & Reverse & TGG CTG ATT GCC GCT GTG CA & \\
\hline \multirow[t]{2}{*}{ ISH } & Erbb3 & Forward & ACA ATG GCC GGA GCT GTC CC & 855 \\
\hline & & Reverse & ACA GCT GCC GGT TGG CAC TT & \\
\hline \multirow[t]{2}{*}{ ISH } & Erbb4 & Forward & CTG GCC GAT GCT GGG GAC CAT & 990 \\
\hline & & Reverse & GGC ATG ACA GGC ACT GGT CCG & \\
\hline
\end{tabular}

Erbb: Erythroblastic leukemia viral oncogene; Egfr: epidermal growth factor receptor; Gapdh: glyceraldehyde 3-phosphate dehydrogenase; ISH: in situ hybridization; qPCR: quantitative polymerase chain reaction.

quantification, copy numbers of Egfr, Erbb2, Erbb3, Erbb4 and, Gapdh were quantified by using a standard curve of known cDNA copy numbers.

Cloning of Erbb DNA probes. Egfr-, Erbb2-, and Erbb3-specific amplicons were generated by RT-PCR from RNA derived from auricular VX2 tumor tissue using Phusion Hot Start II DNA Polymerase (New England Biolabs, Frankfurt, Germany) in combination with the respective ISH primers (eurofins, Nuremberg, Germany) as listed in Table I. The resulting amplicons were gel purified using NucleoSpin ${ }^{\mathrm{TM}}$ Gel and PCR Clean-up Kit (Macherey \& Nagel GmbH, Düren, Germany) and cloned into pGEM-T easy vector using the pGEM $^{\circledR}$-T Vector System I (Promega GmbH, Mannheim, Germany). The vector containing the respective Erbbspecific amplicon was used to transform competent $\mathrm{NEB}^{\circledR} 10$-beta Escherichia coli cells (New England Biolabs) following the manufacturer's protocol. Single clones were generated and $E g f r$, $E r b b 2$, and $E r b B 3$ recombinant vectors were purified (QIAprep Spin Miniprep Kit; Qiagen). The level of sequence identity of the cloned $E g f r, E r b b 2$, and Erbb3 amplicons to the respective reference sequences was confirmed by sequence analysis (Seqlab, Goettingen, Germany).

Preparation of Egfr-, Erbb2-, and Erbb3-specific cRNA probes. Recombinant plasmids were linearized with the appropriate restriction enzymes (NotI or NcoI; New England Biolabs) and transcribed to antisense or sense cRNA using SP6 or T7 polymerase, respectively. In vitro transcription was performed in the presence of ${ }^{35}$ S-UTP (New England Nuclear, Dreieich, Germany) followed by treatment with RNase-free-DNase (Qiagen) for $15 \mathrm{~min}$ at $37^{\circ} \mathrm{C}$. To generate fragments of approximately 250 bp (for optimal intracellular translocation of the probes), ${ }^{35} \mathrm{~S}$-Labeled cRNAs were hydrolyzed in sodium carbonate (final concentration $0.1 \mathrm{M}, \mathrm{pH}$ 10.2 ) at $60^{\circ} \mathrm{C}$ according to the protocol provided by Angerer et al.
(20). Hydrolysis was stopped by the addition of acetic acid to a final concentration of $0.5 \%(\mathrm{v} / \mathrm{v})$, followed by immediate purification of the probes using Micro Bio-Spin Chromatography columns as described in the instruction manual (Bio-Rad, Munich, Germany). For ISH, all labeled cRNA probes were diluted in hybridization buffer $(100 \mathrm{mM}$ Tris pH 7.5, $600 \mathrm{mM} \mathrm{NaCl}, 1 \mathrm{mM}$ EDTA, $0.5 \mathrm{mg} / \mathrm{ml}$ tRNA, $0.1 \mathrm{mg} / \mathrm{ml}$ sonicated salmon sperm DNA, $1 \mathrm{x}$ Denhardts, $10 \%$ dextran-sulfate, $50 \%$ formamide) to a final activity of $50,000 \mathrm{cpm} / \mu \mathrm{l}$. All ISH assays were performed with both antisense and sense cRNA probes.

In situ hybridization. Serial $14 \mu \mathrm{m}$ cryostat sections of tumor tissues were fixed in $4 \%$ formaldehyde at $4^{\circ} \mathrm{C}$ for $1 \mathrm{~h}$, washed three times in phosphate-buffered saline (PBS), penetrated by $0.4 \%$ Triton X-100 in PBS for $5 \mathrm{~min}$ and acetylated for $10 \mathrm{~min}$ in $0.1 \mathrm{M}$ triethanolamine (pH 8.0) with $0.25 \%$ acetic anhydride. Tissues were washed $2 \mathrm{x}$ in saline-sodium citrate (SSC) and dehydrated in ethanol. Hybridization of cellular mRNA with Egfr-, Erbb2-, and Erbb3-specific cRNAs, prepared by in vitro transcription, was achieved after incubating 35 $\mu \mathrm{l}$ of cRNA on tissue sections for $16-18 \mathrm{~h}$ at $52^{\circ} \mathrm{C}$ in a moist chamber. Sections were washed in 2x SSC and 1x SSC for $10 \mathrm{~min}$, followed by digestion of single-stranded non-hybridized RNA with $10 \mu \mathrm{g} / \mathrm{ml}$ RNAse A and $1 \mathrm{U} / \mathrm{ml}$ T1 RNAse (both Roche, Mannheim, Germany) in the presence of Tris/EDTA ( $\mathrm{pH} \mathrm{8.0)}$ ), and $150 \mathrm{mM} \mathrm{NaCl}$ for $1 \mathrm{~h}$ at $37^{\circ} \mathrm{C}$. Subsequently, sections were desalted with 1x SSC, $0.5 x$ SSC and $0.2 \mathrm{x}$ SSC for $10 \mathrm{~min}$ followed by incubation in $0.2 \mathrm{x}$ SSC for $1 \mathrm{~h}$ at $60^{\circ} \mathrm{C}$. Finally, the tissue sections were washed in water for $10 \mathrm{~min}$, dehydrated with ethanol and air dried. Autoradiograms were generated by exposing the sections to autoradiography film (Hyperfilm-MP; Amersham, Dreieich, Germany) for 1-3 days, followed by coating of sections with Kodak NTB2 film emulsion (Fisher Scientific GmbH, Schwerte, Germany). Coated tissues were developed with D19 Kodak developer (Fisher Scientific GmbH) and fixed with Ilford Hypam Fixer (llford, Cheshire, UK) after 15-25 days 
and counterstained with hematoxylin/eosin. Sense probes served as a negative control and never generated any signal above the background level.

Antibodies. Anti-EGFR (cetuximab, Erbitux ${ }^{\circledR} ; 2 \mu \mathrm{g} / \mu \mathrm{l}$, dilution 1:100; Merck KGaA, Darmstadt, Germany); anti-ERBB2 [Neu (F11)] and anti-ErbB3 [ErbB3 (G-4)] (both from Santa Cruz Biotechnology Inc. Heidelberg, Germany) and anti-mitogenactivated protein kinase, activated diphosphorylated extracellular signal-regulated kinase 1/2 (ERK1/2) (monoclonal, clone MAPKYT; Sigma-Aldrich) were deployed in immunohistochemistry. Antihuman IgG [Biotin-SP-AffiniPure F(ab')2 Fragment Goat antiHuman $\operatorname{Ig} \mathrm{A}+\operatorname{IgG}+\operatorname{IgM}(\mathrm{H}+\mathrm{L})$; Dianova $\mathrm{GmbH}$, Hamburg, Germany] was used to detect the humanized chimeric antibody cetuximab. The EnVision+ System horseradish peroxidase (HRP)labeled polymer (K4001; Dako, Glostrup, Denmark) was deployed to detect mouse antibodies directed against ERBB2 and -3 and active ERK1/2 during immunohistochemistry. Primary antibodies directed against active ERK1/2 and beta-actin (mouse monoclonal; Sigma) were used for western blot analysis followed by their detection with HRP-conjugated mouse IgG kappa binding protein (Santa Cruz Biotechnology).

Immunohistochemistry. Surgically removed tumors were fixed in $4 \%$ formaldehyde/PBS (pH 7.2). After dehydration in a graded series of 2-propanol solutions, tissues were embedded in paraffin. Serial 7 $\mu \mathrm{m}$-thick tissue sections were deparaffinized in Roti ${ }^{\circledR}$-Histol (Carl Roth, Karlsruhe, Germany) and endogen peroxidase activity was blocked by incubation of tissue slices in a $3 \% \mathrm{H}_{2} \mathrm{O}_{2}$ methanol solution for $30 \mathrm{~min}$ followed by rehydration in serially diluted 2propanol solutions. To preserve optimal antigen retrieval, sections were incubated for $15 \mathrm{~min}$ at $95^{\circ} \mathrm{C}$ in $10 \mathrm{mM}$ sodium citrate buffer, pH 6.0. After cooling for $30 \mathrm{~min}$, slices were blocked for $30 \mathrm{~min}$ with $10 \%$ normal goat serum (Dako) in PBS prior to incubation with antibodies to ERBB2, ERBB3 or ERK1/2, and 5\% bovine serum albumin/PBS prior exposure to cetuximab for EGFR, then washed and incubated with the respective primary antibodies overnight at $4^{\circ} \mathrm{C}$, followed by incubation at $37^{\circ} \mathrm{C}$ for $1 \mathrm{~h}$ the next day. Subsequently, slices were washed three times for $5 \mathrm{~min}$ in PBS followed by detection of cetuximab binding which was achieved by incubation with a biotinylated secondary anti-human IgG antibody and treatment with avidin/biotin/peroxidase complex (ABC Elite). Detection of anti-ERBB2, anti-ERBB3 and anti-ERK1/2 binding was achieved with the EnVision+ System HRP-labeled polymer (Dako, Glostrup, Denmark). Chromogen signals (brown precipitates) were generated by peroxidase activity after incubation with (3,3'-diaminobenzidine. Tissue slices were counterstained with Mayer's hemalaun solution (Merck). No non-specific reactivity was detected when using corresponding normal IgG (Dako) instead of the primary antibody. Staining results were documented qualitatively with an Olympus Provis AX70 bright field microscope (Olympus Optical, Tokyo, Japan).

Sodium dodecyl sulfate-polyacrylamide gel electrophoresis (SDS$P A G E)$ and western blot analysis. To evaluate protein expression levels, SDS-PAGE (10\%) and western blot analysis were performed with the antibodies indicated above under standard laboratory conditions as described elsewhere (21).

Statistical analysis. GraphPad Prism Software 6.0 (GraphPad Software Inc., San Diego, CA, USA) was used for statistical evaluation. The two-tailed, unpaired Student's $t$-test was implemented to evaluate differences between the $\mathrm{O}_{3} / \mathrm{O}_{2} \mathrm{PP}$-and sham-treated groups. A value of $p<0.05$ was considered to represent significant differences between groups. Welch's correction was applied whenever variances of the group means differed significantly.

\section{Results}

Progressive growing of VX2 carcinomas were compared with regressing tumors. One feature of the VX2 animal model is that spontaneous remission of the tumor is observed in up to $25 \%$ of cases, pointing to the inherent potential of the NZW rabbit to reject the VX2 carcinoma. The remission rate of auricular VX2 tumor can be increased to $70 \%$ when applying $\mathrm{O}_{3} / \mathrm{O}_{2}$-PP (18). Here, the $\mathrm{O}_{3} / \mathrm{O}_{2}$-PP treatment was used to generate a high number of regressing tumors. Two regressive and two progressive tumors were used as a first approach to compare gene-expression profiles between the two groups, which should indicate possible candidate genes associated with tumor remission.

Gene-expression profiles of progressive compared with regressive VX2 tumors. Figure $1 \mathrm{~A}$ and $\mathrm{B}$ depict the macroscopic view and growth course of two progressive and two regressive VX2 tumors, respectively. Total mRNA derived from these tumors was used for microarray analysis leading to the detection of 540 distinctive genes (Figure 1C). More detailed analysis of this gene profile focusing on vascular-associated genes pinpointed six candidate genes that significantly differed in their expression levels between the two groups (Figure 1D). It was remarkable to note that only the level of expression of Egfr mRNA demonstrated major (30-fold) down-regulation in regressive tumors, which is in line with the concept that EGFR, as well as other RTKs, promote tumor growth and development.

Quantification of $m R N A$ for ERBB receptors in VX2 tumor tissues. Observation of the major down-regulation of Egfr mRNA in regressive $\mathrm{VX} 2$ tumor tissues prompted us to evaluate the expression of all ERBB RTK family members. qRT-PCR was deployed to confirm down-regulation of Egfr in regressive $\mathrm{VX} 2$ tumor tissues and to analyze the expression pattern of other ERBB receptor family members. To analyze independent samples, we used tumor tissues from an independent VX2 animal study in which $\mathrm{O}_{3} / \mathrm{O}_{2}$-PP was also deployed to generate tumor remission. However, in that study, the criteria for tumor remission were even more stringent (reduction to $<25 \%$ of the tumor's maximal size) than in the present animal study.

Absolute quantification of $E g f$ mRNA confirmed the significant down-regulation of the receptor (Figure 2A) as observed from the microarray analysis. Similarly, although generally having lower expression than Egfr, Erbb2 and Erbb3 mRNAs were also significantly down-regulated in 
A
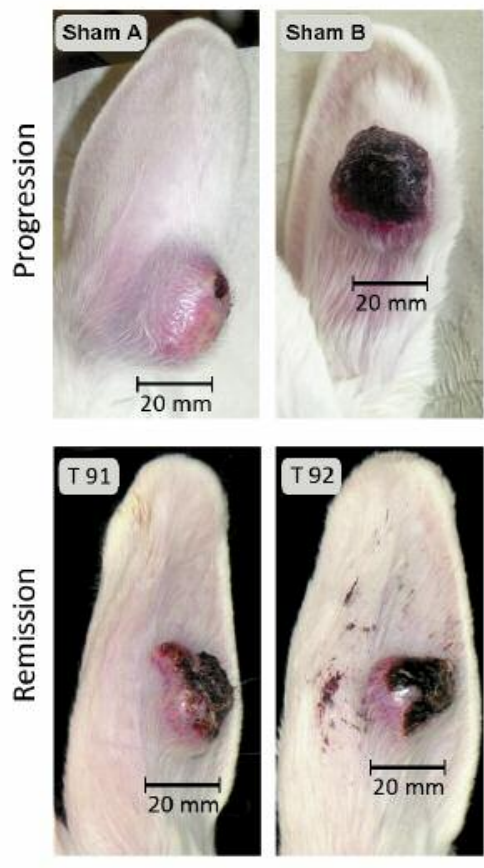

B
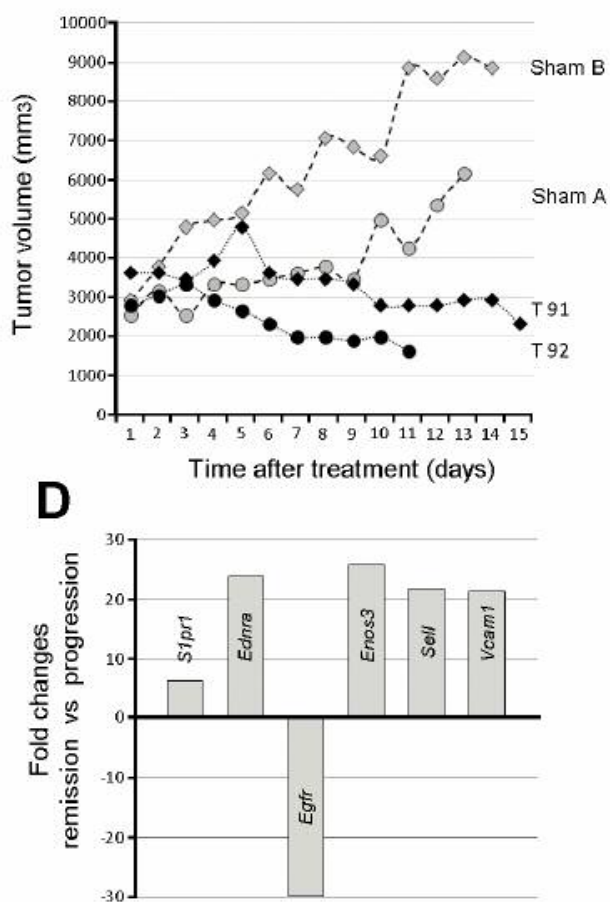

D Time after treatment (days)

C

Figure 1. Growth kinetics and gene profiles of progressive and regressive VX2 tumors. A: Macroscopic view of VX2 tumors in progression or remission (day 10 after treatment). B: Development of tumor volume in sham-(sham $A$ and sham $B$ ) and $\mathrm{O}_{3} / \mathrm{O}_{2}-P P$-treated (T 91 and T 92$)$ animals. C: Hierarchical clustering of 540 selected genes after microarray analysis of VX2 tumor samples. Each column represents one tumor tissue sample and each row refers to one gene. Relative gene-expression levels are depicted according to a color scale in which blue represents the lowest and red the highest level of expression. D: Gene-profile analysis focusing on vascular-associated genes revealed six differentially regulated candidate genes. S1pr1: Sphingosine 1-phosphate receptor 1 (NM_001198946); Ednra: endothelin receptor type A (NM_001105674); Egfr: epidermal growth factor receptor (AF243516); Enos3: endothelial nitric oxide synthase (NM_001082733); Sell: selectin L, (NM_001082352); Vcam1: vascular cell adhesion molecule (NM_001082152).

A

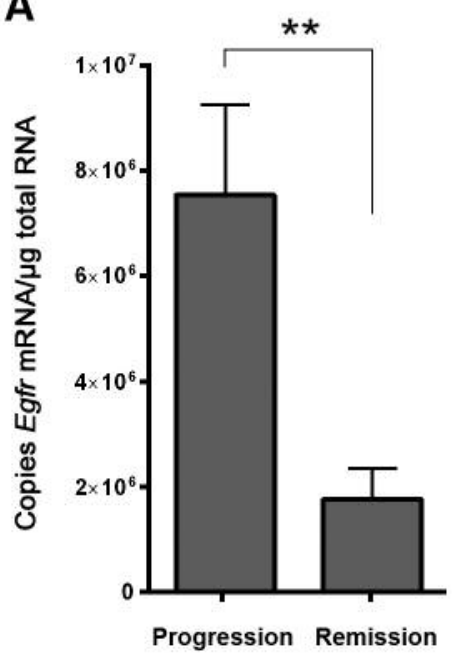

B

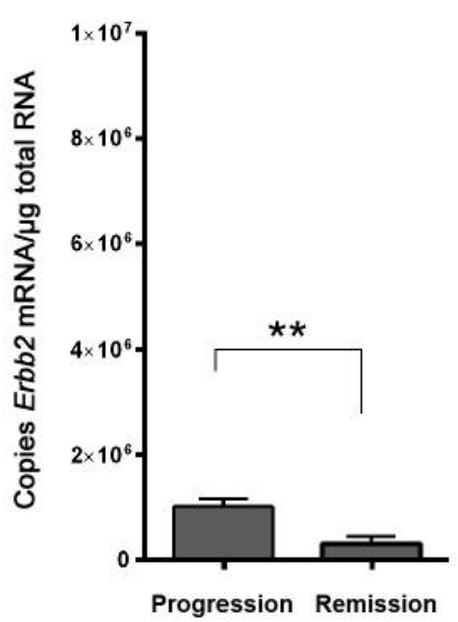

C

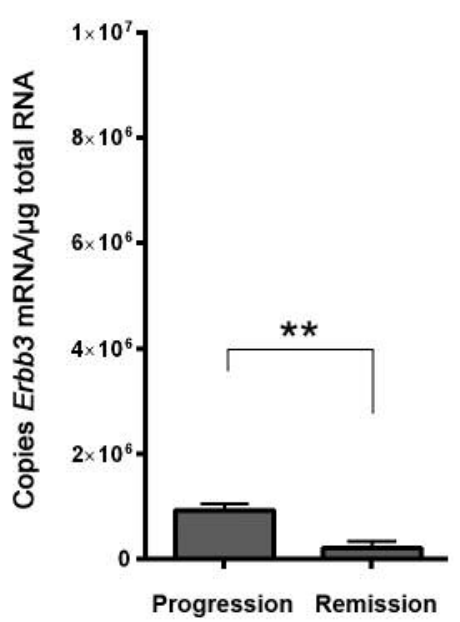

Figure 2. Expression of erythro-blastic leukemia viral oncogene (Erbb) family members in VX2 tumor tissues. Graphs depict the absolute number of A: Egfr, B: Erbb2 and C: Erbb3 mRNA copies per $\mu \mathrm{g}$ total $R N A$ in $O_{3} / O_{2}$-PP-treated progressive $(n=6)$ or regressive $(n=7)$ tumors. Data are the mean \pm SEM. ** Significantly different at $p<0.005$. 

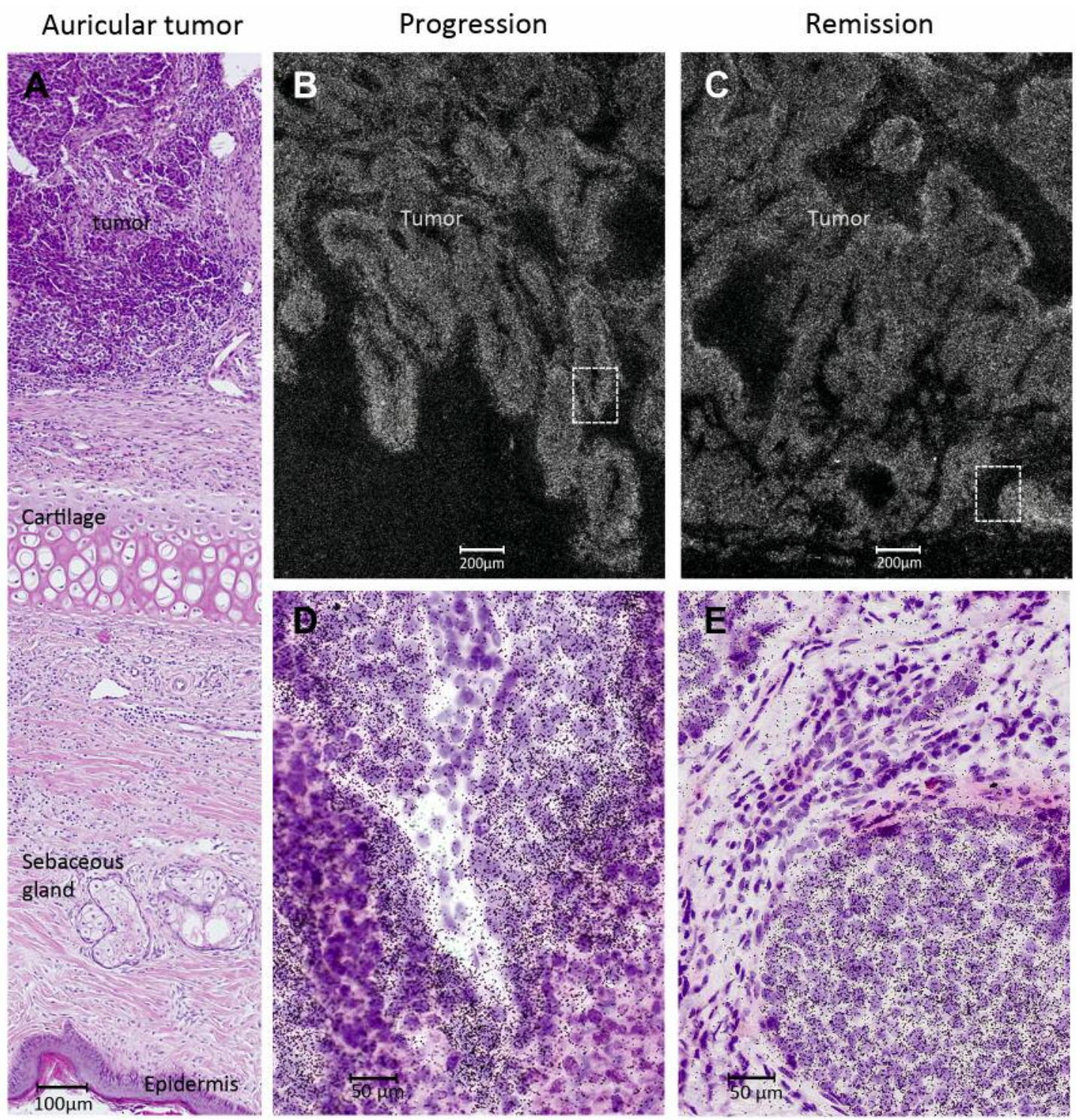

Figure 3. Epidermal growth factor receptor (Egfr) mRNA expression in auricular VX2 tumor tissue. A: Histological overview of an implanted VX2 carcinoma of the rabbit auricle. The epidermis of the ventral skin is shown at the bottom of the image. B: and C: Dark-field microscopy of radioactive-labelled Egfr $m R N A$ (white dots) in tumor cells from progressive and regressive tumors, respectively. $D$ and E: Documentation using bright-field analysis of Egfr mRNA in VX2 tumoral, but not stromal cells from progressive and regressive tumors, respectively. Areas in B and C (dotted boxes) are shown at higher magnification in D and E.

regressive tumors (Figure $2 \mathrm{~B}$ and $\mathrm{C}$ ). In our experimental setting, no Erbb4 mRNA was detected in any of the tumors.

ISH of VX2 tumor tissues using Erbb-specific probes. In order to evaluate which cell types in the tumor express the Erbb mRNAs detected by microarray and qRT-PCR, we generated rabbit Erbb DNA probes for ISH. For PCR cloning, RNA isolated from the original VX2 tumor tissues was deployed. Using the primer pairs listed in Table I we were able to generate rabbit Egfr, Erbb2 and Erbb3 but not Erbb4 DNA fragments. Sequence analysis of the cloned DNA fragments revealed high identity to the published rabbit $(\mathrm{rb})$ reference sequences ( $\mathrm{rb} E g f r$ clone \#4: $99.7 \%$ to XM_008261844.2; rbErbb2 clone \#8; 99.0\% to XM_002719343.3; rbErbb3 clone \#3; $100 \%$ to XM_002711067.1. We were unable to isolate rbErbb4 DNA from VX2 tumor tissues in our experimental settings.

It was found that Erbb receptor mRNAs were predominately expressed by the epithelial portion of the VX2 

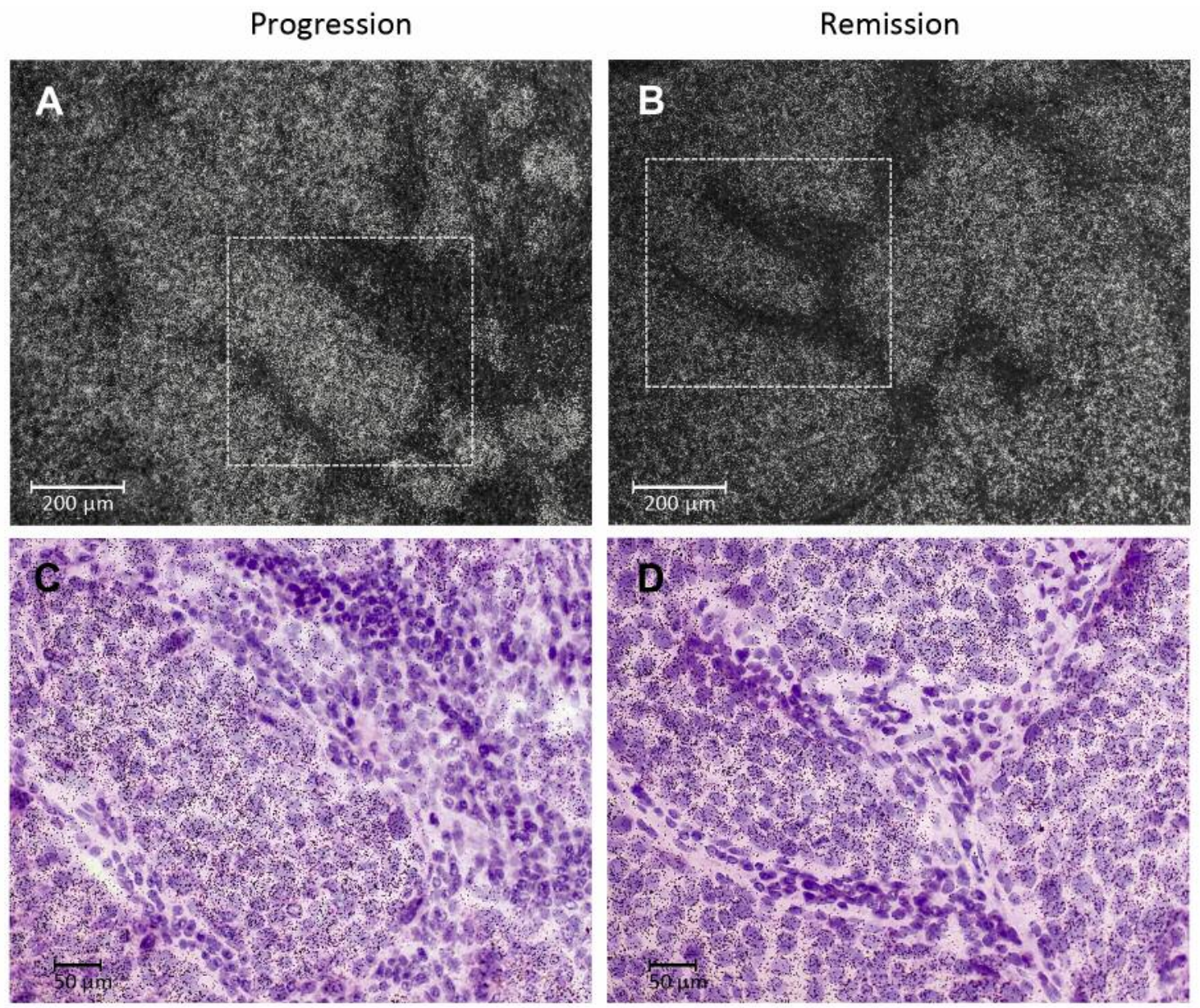

Figure 4. Erythroblastic leukemia viral oncogene 3 (Erbb3) mRNA expression in VX2 tumor cells. A and B: Dark-field analysis; C and D: brightfield detection of areas highlighted in $A$ and $B$ at higher magnification.

tumor (Figures 3-5), which identifies these cells as the major source of the $E r b b$ mRNA measured. In addition, robust expression of Erbb2 mRNA was also seen in normal epithelial cells of the epidermis and sebaceous glands (Figure 4). Similarly, these structures also expressed Egfr and Erbb2 mRNA, although at lower levels (data not shown).

Immunohistochemical analysis of FFPE tissue slices was consistent with the ISH data revealing protein expression of EGFR, ERBB2, and ERBB3 in VX2 tumor cells, as well as in epidermal cells of the skin, outer cells of the hair follicle and in sebaceous glands (Figure 6).

ERBB downstream signaling in VX2 tumors. In order to assess if ERBB signaling is functional in VX2 tumor cells, we evaluated expression of major ERBB downstream signaling intermediates, such as MAPK2K1 as well as the presence of active ERK1/2. Active ERK1/2 was detected by western blot analysis and immunohistochemistry. Consistent with its being in its active form, ERK1/2 exhibited major nuclear localization and was also detected in normal epithelial cells such as cells of the epidermis, hair follicles and sebaceous glands (Figure 7) that also expressed EGFR, ERBB2 and ERBB3. Similarly, Mapk2kl transcript levels were detected in progressive and regressive tumors at similar expression levels by qRT-PCR analysis.

\section{Discussion}

RTKs of the ERBB family are essential for the regulation of numerous biological outcomes such as cell proliferation, differentiation, adhesion and migration. EGFR (ERBB1), the most prominent representative of the RTK family, is particularly responsible for the maintenance of epithelial cell growth (22). Mutation or overexpression of ERBB receptors are often associated with the development and progression of human malignancies in which distinct ERBB RTK members 

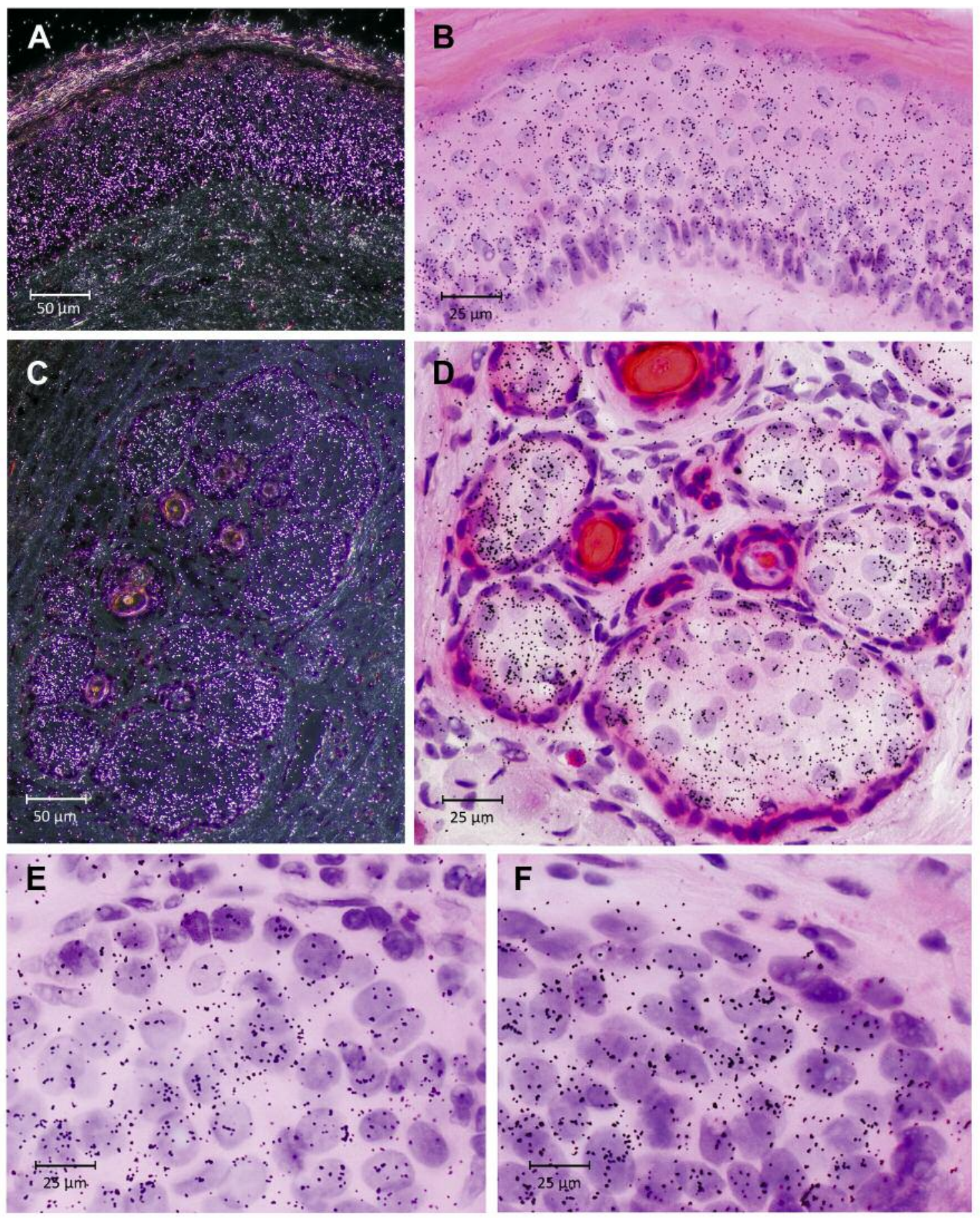

Figure 5. Erythroblastic leukemia viral oncogene 2 (Erbb2) expression in rabbit skin and VX2 tumor tissues. Detection of Erbb2 mRNA in the epidermis $(A, B)$ and sebaceous glands $(C, D)$ by dark-field $(A, C)$ and bright-field $(B, D-F)$ microscopy. Erbb2 mRNA was expressed in VX2 cells of progressive $(E)$ and regressive $(F)$ tumors.

exhibit a decisive role depending on the tumor entity $(3,23-$ 25). Mutation or overexpression of EGFR (e.g. by gene amplification) has been implicated in the carcinogenesis and disease progression of more than $90 \%$ of all HNSCC cases
(26-28). Furthermore, several studies demonstrated EGFR to be associated with an increased tumor size, risk of recurrence, and decreased therapeutic sensitivity (29-33). However, less attention has been paid to its role as a diagnostic marker. 



Figure 6. Protein expression of epidermal growth factor receptor (EGFR) and erythroblastic leukemia viral oncogene (ERBB) receptors. A-D: EGFR; E-H: ERBB2 and I-M: ERBB3 were expressed in VX2 tumor cells, skin, hair follicle and sebaceous glands.

Here we present data of ERBB receptor expression in an experimental animal tumor (VX2 carcinoma of the NZW rabbit) which serves as a model system for human HNSCC. In previous studies, we reported that application of $\mathrm{O}_{3} / \mathrm{O}_{2}-\mathrm{PP}$ is an effective approach to initiate processes leading to remission of solid auricular VX2 squamous cell carcinomas in the NZW rabbit animal model $(18,19)$. Deploying the $\mathrm{O}_{3} / \mathrm{O}_{2}$-PP treatment we were able to induce VX2 tumor remission. To identify possible candidate genes that may contribute to such remission, here the mRNA expression profile of progressive and regressive tumors was evaluated by microarray analysis. Amongst other candidate genes, we identified $E g f r$ as a major differentially regulated gene. $E g f r$ mRNA expression level dropped by a factor of 30 in regressive tumor tissues compared to tumors in progression.

Further evaluation of Egfr mRNA expression levels by qPCR confirmed its significant down-regulation in regressive tumors. This implies that progressively growing VX2 tumors exhibit significantly higher Egfr mRNA levels, which is in line with the observed overexpression of EGFR in up to $90 \%$ of human HNSCC (26). In this context, elevated EGFR copy numbers were found to be associated with reduced survival in patients with HNSCC (34). However, other, studies failed to prove a correlation of altered EGFR mRNA or protein levels and clinical outcome (7).

The role of ERBB2 in HNSCC is less understood, but studies have demonstrated an increased ERBB2 expression in a large percentage of patients with oral HNSCCs (35-37). 

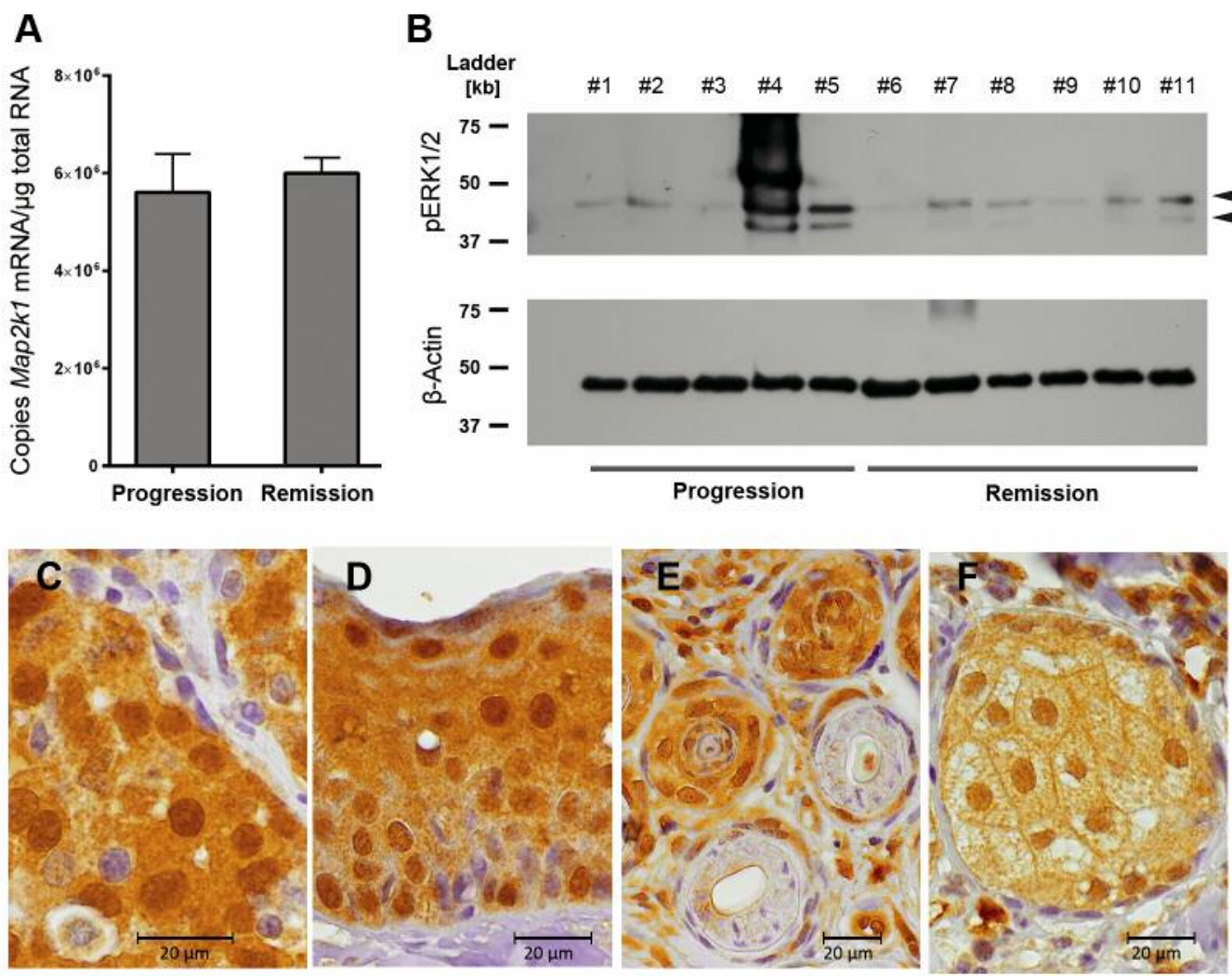

Figure 7. Expression of erythroblastic leukemia viral oncogene (ERBB) downstream signaling intermediates. A: Comparison of mitogen-activated protein kinase kinase 1 (MAPK2K1) expression in tumor tissues. B: Western blot analysis of active (phosphorylated) extracellular signal-regulated kinase 1/2 (ERK1/2) in homogenates of different tumors in progression (lanes 1-5) and remission (lanes 6-11). Arrowheads point to phospho-ERK1/2specific bands. Immunohistochemical detection of active ERK1/2 in C: VX2 tumor, D: epidermis, E: hair follicles and F: sebaceous gland. Note the predominant nuclear localization of active ERK1/2.

Western blot and immunohistochemical analyses highlight variable ERBB2 expression which, however, appears to be limited to a subset of HNSCC tumors and cell lines. Expression of ERBB2 was found to be highly regulated at the transcriptional or post-transcriptional level (35). Published data of ERBB2 overexpression and its correlation with HNSCC disease progression and survival are controversial $(38,39)$ and its role as a reliable marker for HNSCC is incompletely understood. This in part appears to be due to the lack of a ligand-binding domain in ERBB2 and its function rather as an amplifier of ERBB receptor activation (40), thereby masking its possible impact on HNSCC. Upon ligand binding, monomeric ERBB receptors are activated through homo-or heterodimerization with other members of the ERBB family (41). ERBB2 is unique since it does not homodimerize under normal conditions and its ectodomain does not bind ligands $(42,43)$. There is evidence that ERBB2 is the preferred dimerization partner for all other members of the ERBB receptor family after ligand binding $(42,44,45)$, which has led to the suggestion of it having a key function in ERBB RTK activation (43).

Especially when overexpressed, ERBB2 can maintain tumorigenesis caused by other ERBB receptor family members. Many tumors which express a high level of ERBB2 also express ERBB3 (12), suggesting that ERBB2ERBB3 heterodimers are required for ERBB-mediated signaling in tumor cells. Indeed, the existence of ERBB2ERBB3 heterodimers forming functional oncogenic units that drive tumor cell proliferation have been experimentally verified by Holbro and colleagues using different breast cancer cell lines (46).

In VX2 rabbit tumor, we observed expression of EGFR, ERBB2 and ERBB3. ERBB4 was not detected in VX2 carcinoma during our analyses. VX2 cells thereby carry the potential to form heterodimers between these three ERBB representatives. Detection of Mapk $2 k 1$ mRNA in VX2 tumor tissues, as well as immunohistochemical detection of activated ERK1/2, points to an active rat sarcoma (RAS) rapidly accelerated fibrosarcoma (RAF)-MAPK2K1-ERK1/2 signaling pathway. However, we did not detect obvious 
changes in the activation status of this pathway in progressive and regressive tumors. In human cancer, this pathway is frequently up-regulated and over activated, thereby serving as an attractive target for anticancer drugs (47).

This study highlights changes in the Erbb gene signature of rabbit VX2 carcinomas as a possible predictor for therapy response. Further studies will have to evaluate if and how this information is applicable to diagnostic, prognostic and therapeutic procedures in the human patient.

\section{Acknowledgements}

The Authors thank Mrs. R. Peldszus and G. Sadowski for preparation of the VX2 tumor cell suspension, and Mrs. M. Zibuschka and H. Hlawaty for assistance with the histological analysis. This research was funded in part by the Wirtschafts-und Infrastrukturbank Hessen (TM MBF-P_04/2009).

\section{References}

1 Downward J, Yarden Y, Mayes E, Scrace G, Totty N, Stockwell $\mathrm{P}$, Ullrich A, Schlessinger J and Waterfield MD: Close similarity of epidermal growth factor receptor and $v$-erb- $B$ oncogene protein sequences. Nature 307: 521-527, 1984.

2 Appert-Collin A, Hubert P, Cremel G and Bennasroune A: Role of ErbB receptors in cancer cell migration and invasion. Front Pharmacol 6: 283, 2015.

3 Holbro T and Hynes NE: ErbB receptors: directing key signaling networks throughout life. Annu Rev Pharmacol Toxicol 44: 195217, 2004.

4 Leemans CR, Braakhuis BJ and Brakenhoff RH: The molecular biology of head and neck cancer. Nat Rev Cancer 11: 9-22, 2011.

5 Ibrahim SO, Vasstrand EN, Liavaag PG, Johannessen AC and Lillehaug JR: Expression of $c$-erbB proto-oncogene family members in squamous cell carcinoma of the head and neck Anticancer Res 17: 4539-4546, 1997.

6 Rodrigo JP, Ramos S, Lazo PS, Alvarez I and Suarez C: Amplification of ERBB oncogenes in squamous cell carcinomas of the head and neck. Eur J Cancer 32A: 2004-2010, 1996.

7 Chung CH, Ely K, McGavran L, Varella-Garcia M, Parker J, Parker N, Jarrett C, Carter J, Murphy BA, Netterville J, Burkey BB, Sinard R, Cmelak A, Levy S, Yarbrough WG, Slebos RJ and Hirsch FR: Increased epidermal growth factor receptor gene copy number is associated with poor prognosis in head and neck squamous cell carcinomas. J Clin Oncol 24: 4170-4176, 2006.

8 Beck TN, Georgopoulos R, Shagisultanova EI, Sarcu D, Handorf EA, Dubyk C, Lango MN, Ridge JA, Astsaturov I, Serebriiskii IG, Burtness BA, Mehra R and Golemis EA: EGFR and RB1 as dual biomarkers in HPV-negative head and neck cancer. Mol Cancer Ther 15: 2486-2497, 2016.

9 Bossi P, Resteghini C, Paielli N, Licitra L, Pilotti S and Perrone F: Prognostic and predictive value of EGFR in head and neck squamous cell carcinoma. Oncotarget 7: 74362-74379, 2016.

10 Pollock NI, Wang L, Wallweber G, Gooding WE, Huang W, Chenna A, Winslow J, Sen M, DeGrave KA, Li H, Zeng Y and Grandis JR: Increased expression of HER2, HER3, and HER2:HER3 heterodimers in HPV-positive HNSCC using a novel proximity-based assay: implications for targeted therapies. Clin Cancer Res 21: 4597-4606, 2015.
11 Gutierrez C and Schiff R: HER2: biology, detection, and clinical implications. Arch Pathol Lab Med 135: 55-62, 2011.

12 Baselga $J$ and Swain SM: Novel anticancer targets: revisiting ERBB2 and discovering ERBB3. Nat Rev Cancer 9: 463-475, 2009.

13 Ford AC and Grandis JR: Targeting epidermal growth factor receptor in head and neck cancer. Head Neck 25: 67-73, 2003.

14 Dunne AA, Mandic R, Ramaswamy A, Plehn S, Schulz S, Lippert BM, Moll R and Werner JA: Lymphogenic metastatic spread of auricular VX2 carcinoma in New Zealand white rabbits. Anticancer Res 22: 3273-3279, 2002.

15 van Es RJ, Dullens HF, van der Bilt A, Koole R and Slootweg PJ: Evaluation of the VX2 rabbit auricle carcinoma as a model for head and neck cancer in humans. J Craniomaxillofac Surg 28: 300-307, 2000.

16 Georges E, Breitburd F, Jibard N and Orth G: Two Shope papillomavirus-associated VX2 carcinoma cell lines with different levels of keratinocyte differentiation and transplantability. J Virol 55: 246-250, 1985.

17 Shope RE and Hurst EW: Infectious Papillomatosis of Rabbits : With a Note on the Histopathology. J Exp Med 58: 607-624, 1933.

18 Rossmann A, Mandic R, Heinis J, Hoffken H, Kussner O, Kinscherf R, Weihe $\mathrm{E}$ and Bette $\mathrm{M}$ : Intraperitoneal oxidative stress in rabbits with papillomavirus-associated head and neck cancer induces tumoricidal immune response that is adoptively transferable. Clin Cancer Res 20: 4289-4301, 2014.

19 Schulz S, Haussler U, Mandic R, Heverhagen JT, Neubauer A, Dunne AA, Werner JA, Weihe E and Bette M: Treatment with ozone/oxygen-pneumoperitoneum results in complete remission of rabbit squamous cell carcinomas. Int J Cancer 122: 23602367, 2008.

20 Angerer LM, Cox KH, Angerer RC, Willerford DM, Chen J, Ferry JA, Davidson L, Ma A and Alt FW: Demonstration of tissue-specific gene expression by in situ hybridization. Methods Enzymol 152: 649-661, 1987.

21 Mandic R, Schamberger CJ, Muller JF, Geyer M, Zhu L, Carey TE, Grenman R, Dunne AA and Werner JA: Reduced cisplatin sensitivity of head and neck squamous cell carcinoma cell lines correlates with mutations affecting the $\mathrm{COOH}$-terminal nuclear localization signal of p53. Clin Cancer Res 11: 6845-6852, 2005.

22 Eccles SA: The epidermal growth factor receptor/Erb-B/HER family in normal and malignant breast biology. Int J Dev Biol 55: 685-696, 2011.

23 Mishra R, Hanker AB and Garrett JT: Genomic alterations of ERBB receptors in cancer: clinical implications. Oncotarget 8 : 114371-114392, 2017.

24 Molinolo AA, Amornphimoltham P, Squarize CH, Castilho RM, Patel V and Gutkind JS: Dysregulated molecular networks in head and neck carcinogenesis. Oral Oncol 45: 324-334, 2009.

$25 \mathrm{Du} \mathrm{Z}$ and Lovly CM: Mechanisms of receptor tyrosine kinase activation in cancer. Mol Cancer 17: 58, 2018.

26 Grandis JR and Tweardy DJ: Elevated levels of transforming growth factor alpha and epidermal growth factor receptor messenger RNA are early markers of carcinogenesis in head and neck cancer. Cancer Res 53: 3579-3584, 1993.

27 Ha PK, Chang SS, Glazer CA, Califano JA and Sidransky D: Molecular techniques and genetic alterations in head and neck cancer. Oral Oncol 45: 335-339, 2009. 
28 Rubin Grandis J, Melhem MF, Barnes EL and Tweardy DJ: Quantitative immunohistochemical analysis of transforming growth factor-alpha and epidermal growth factor receptor in patients with squamous cell carcinoma of the head and neck. Cancer 78: 1284-1292, 1996.

29 Zimmermann M, Zouhair A, Azria D and Ozsahin M: The epidermal growth factor receptor (EGFR) in head and neck cancer: its role and treatment implications. Radiat Oncol 1: 11, 2006.

30 Ang KK, Berkey BA, Tu X, Zhang HZ, Katz R, Hammond EH, Fu KK and Milas L: Impact of epidermal growth factor receptor expression on survival and pattern of relapse in patients with advanced head and neck carcinoma. Cancer Res 62: 7350-7356, 2002.

31 Normanno N, De Luca A, Bianco C, Strizzi L, Mancino M, Maiello MR, Carotenuto A, De Feo G, Caponigro F and Salomon DS: Epidermal growth factor receptor (EGFR) signaling in cancer. Gene 366: 2-16, 2006.

32 Numico G, Russi EG, Colantonio I, Lantermo RA, Silvestris N, Vitiello R, Comino A, Abrate M, Zavattero C, Melano A and Merlano M: EGFR status and prognosis of patients with locally advanced head and neck cancer treated with chemoradiotherapy. Anticancer Res 30: 671-676, 2010.

33 Rabinowits $\mathrm{G}$ and Haddad RI: Overcoming resistance to EGFR inhibitor in head and neck cancer: a review of the literature. Oral Oncol 48: 1085-1089, 2012.

34 Temam S, Kawaguchi H, El-Naggar AK, Jelinek J, Tang H, Liu DD, Lang W, Issa JP, Lee JJ and Mao L: Epidermal growth factor receptor copy number alterations correlate with poor clinical outcome in patients with head and neck squamous cancer. J Clin Oncol 25: 2164-2170, 2007.

35 Beckhardt RN, Kiyokawa N, Xi L, Liu TJ, Hung MC, el-Naggar AK, Zhang HZ and Clayman GL: HER-2/neu oncogene characterization in head and neck squamous cell carcinoma. Arch Otolaryngol Head Neck Surg 121: 1265-1270, 1995.

36 Field JK, Spandidos DA, Yiagnisis M, Gosney JR, Papadimitriou $\mathrm{K}$ and Stell PM: C-erbB-2 expression in squamous cell carcinoma of the head and neck. Anticancer Res 12: 613-619, 1992.

37 Craven JM, Pavelic ZP, Stambrook PJ, Pavelic L, Gapany M, Kelley DJ, Gapany S and Gluckman JL: Expression of $c$-erbB-2 gene in human head and neck carcinoma. Anticancer Res 12: 2273$2276,1992$.
38 Xia W, Lau YK, Zhang HZ, Liu AR, Li L, Kiyokawa N, Clayman GL, Katz RL and Hung MC: Strong correlation between c-erbB2 overexpression and overall survival of patients with oral squamous cell carcinoma. Clin Cancer Res 3: 3-9, 1997.

39 Khan AJ, King BL, Smith BD, Smith GL, DiGiovanna MP, Carter D and Haffty BG: Characterization of the HER-2/neu oncogene by immunohistochemical and fluorescence in situ hybridization analysis in oral and oropharyngeal squamous cell carcinoma. Clin Cancer Res 8: 540-548, 2002.

40 Arkhipov A, Shan Y, Kim ET, Dror RO and Shaw DE: Her2 activation mechanism reflects evolutionary preservation of asymmetric ectodomain dimers in the human EGFR family. Elife 2: e00708, 2013.

41 Olayioye MA, Neve RM, Lane HA and Hynes NE: The ErbB signaling network: receptor heterodimerization in development and cancer. EMBO J 19: 3159-3167, 2000.

42 Tzahar E, Waterman H, Chen X, Levkowitz G, Karunagaran D, Lavi S, Ratzkin BJ and Yarden Y: A hierarchical network of interreceptor interactions determines signal transduction by $\mathrm{Neu}$ differentiation factor/neuregulin and epidermal growth factor. Mol Cell Biol 16: 5276-5287, 1996.

43 Citri A and Yarden Y: EGF-ERBB signalling: towards the systems level. Nat Rev Mol Cell Biol 7: 505-516, 2006.

44 Lenferink AE, Pinkas-Kramarski R, van de Poll ML, van Vugt MJ, Klapper LN, Tzahar E, Waterman H, Sela M, van Zoelen EJ and Yarden Y: Differential endocytic routing of homo- and heterodimeric ErbB tyrosine kinases confers signaling superiority to receptor heterodimers. EMBO J 17: 3385-3397, 1998.

45 Graus-Porta D, Beerli RR, Daly JM and Hynes NE: ErbB-2, the preferred heterodimerization partner of all ErbB receptors, is a mediator of lateral signaling. EMBO J 16: 1647-1655, 1997.

46 Holbro T, Beerli RR, Maurer F, Koziczak M, Barbas CF, 3rd and Hynes NE: The ErbB2/ErbB3 heterodimer functions as an oncogenic unit: ErbB2 requires ErbB3 to drive breast tumor cell proliferation. Proc Natl Acad Sci USA 100: 8933-8938, 2003.

47 Kohno $\mathrm{M}$ and Pouyssegur J: Targeting the ERK signaling pathway in cancer therapy. Ann Med 38: 200-211, 2006. 